\title{
The Performability and Speakability Dimensions of Translated Drama Texts
}

\section{Suh Joseph Che}

\begin{abstract}
This paper highlights the divergent views drama translation scholars hold on the issues of performability and speakability in translated drama. It argues and asserts that since drama is essentially rooted in a given culture, instead of seeking to determine universals of performability in all drama texts indistinctly, the researcher could attain more pertinent findings whose syntheses and applicability could be more readily and concretely related to the given culture, period and drama type. Finally, it posits that drama translators and scholars could achieve more useful and concrete results by examining closely and analyzing what directors and performers in each culture/region actually do to the text for it to be performable or speakable in conformity with the norms and conventions of the given culture/region.
\end{abstract}

Drama translation scholars have been interested in the specific characteristics of drama which distinguish this genre from the other literary genres and are thus expected to have an incidence on its translation. Prominent amongst such characteristics are performability and speakability. These two notions, often regarded as fundamental to and characteristic of drama, and which represent the gestic/action and oral/acoustic dimensions of the drama text, have animated discussion amongst drama translation scholars over

Translation Today Vol. 2 No. 2 Oct. 2005 @ CIIL 2005 
the past three decades and indeed continue to sustain active debate amongst them.

As Bassnett (1991:99) has pointed out, in the twentieth century, the notion of a gestural dimension that is seen as inherent in the language of a theatre text has become an issue of considerable importance. And this is evident from the fact that many scholars and theoreticians (cf. Wellwarth 1981, Ubersfeld 1978, Elam 1980, Helbo 1987, Bassnett 1991, Moravkova 1993, Aaltonen 2000, Upton 2000) have successively, over the years, attempted to define the nature of the relationship between the verbal text on the page and the gestic dimension somehow embedded in the text waiting to be realized in performance.

Susan Bassnett stands out as one of the scholars who have consistently given this aspect in-depth and critical thought (cf. Bassnett 1980, 1991, 1998). The first issue raised by this eminent scholar with respect to the notion of performability is that of its definition. In effect, she asserts that:

"The term 'performability' is frequently used to describe the undescribable, the supposedly existent concealed gestic text within the written. [...] It has never been clearly defined, and indeed does not exist in most languages other than English. Attempts to define the 'performability' inherent in a text never go further than generalized discussion about the need for fluent speech rhythms in the target text. What this amounts to in practice is that each translator decides on an entirely ad hoc basis what constitutes a speakable text for performers. There is no sound theoretical base for arguing that 'performability' can or does exist (Bassnett 1991:102).” 
Several years later, still rejecting the term performability altogether, she declares, "it seems to me a term that has no credibility, because it is resistant to any form of definition" (Bassnett 1998:95). In stating that in practice what this amounts to is that each translator acts on an entirely adhoc basis she does not seem to sufficiently take into consideration the two important factors of general context and situational context surrounding any dramatic text or its translation. Interestingly, as she herself (cf. Bassnett 1991:109) points out, theatre anthropology has established the fact that all forms of theatre vary according to cultural conventions and what needs to be done in each case is to investigate and determine the elements that constitute performance in different cultures. To corroborate this, it can even be argued and asserted further here that in addition to investigating and determining the elements that constitute performance in different cultures, such elements should also be specifically determined for each of the drama types. For instance, African drama, South of the Sahara, alone comprises many types. There are sacred dramas whose subjects and aims are religious. Sacred dramas are in turn sub-divided into ancestral or myth plays, masquerades, plays by age groups and cults, rituals, etc. There are also secular dramas distinct from sacred dramas and include sub-types such as civic dramas, dance and song dramas, etc. Just from this brief and inexhaustive inventory of drama types in the sub-Saharan African region, it is evident that African drama is very varied and complex. It is also evident that each of these types of drama has its own distinctive performability and speakability characteristics which clearly differentiate it from the other types. In this connection, Melrose (1988, in Bassnett 1991:110), theatre analyst and translator, has argued that gestus is culture-bound and cannot be perceived as a universal. In research conducted and which involved working with a multicultural group in workshop conditions, she discovered that the gestic response to written texts depends entirely on the cultural formation of the individual performer, affected by a variety of factors, including theatre 
convention, narrative convention, gender, age, behavioural patterns, etc.

It is Bassnett's very assertive and categorical position with respect to the notion of performability as highlighted in the above quotations that have probably prodded and led other scholars to equally accord the notion in-depth reflection. Espasa (2000:49-61) for instance, and in contrast to Bassnett, examines and analyzes the notion of performability from textual, theatrical and ideological perspectives. In an attempt to clearly circumscribe the notion which Bassnett considers to be "resistant to any form of definition", she starts by synthesizing the terminology related to it. She thus asserts that, "from a textual point of view, performability is often equated with 'speakability' or 'breathability', i.e. the ability to produce fluid texts which performers may utter without difficulty" (Espasa 2000:49). Similarly, she points out that performability is synonymous to and interchangeable with theatricality, playability, actability and theatre specificity (cf. Espasa 2000:49-50). Having related all these terms to the notion of performability she asserts that performability is firstly conditioned by textual and theatrical practices, and that the following definition of theatricality by Pavis is perfectly applicable to performability:

\footnotetext{
"Theatricality does not manifest itself [...] as a quality or an essence which is inherent to a text or a situation, but as a pragmatic use of the scenic instrument, so that the components of the performance manifest and fragment the linearity of the text and of the word (Pavis 1983, in Espasa 2000:52)."
}

The above view of theatricality or performability, running counter to Bassnett's view on the same notion, Surely opens up the debate on this issue. In effect, instead of viewing performability as 
the "gestic dimension embedded in the text, waiting to be realized in performance" (Bassnett 1991:99), Pavis and Espasa consider that it is not a quality or an essence inherent to the text but rather a pragmatic use of the scenic instrument. According to this "pragmatic use of the scenic instrument", one cannot therefore talk about an abstract, universal notion of performability and this is bound to vary depending on the ideology and style of presentation of the company or the cultural milieu. It can thus be said that Bassnett's (1991:102) preoccupation with the notion that "if a set of criteria ever could be established to determine the 'performability' of a theatre text, then those criteria would constantly vary, from culture to culture, from period to period and from text type to text type" need not be regarded as negative but could rather be considered a characteristic of drama and a constraint manifested by this genre which should be taken into consideration in its treatment by the drama translator.

Since drama is essentially rooted in a given culture, it could further be argued and asserted that universal applicability of a set of criteria established to determine performability need not be the main issue. Instead the focus could be on the predictability of such established criteria for a given culture, period or drama type. For instance, in the Cameroonian context and more specifically in the culture of the Bafut tribe for example, the immediate concern of the researcher could first of all be to establish performability criteria in Bafut drama and to determine the predictability and possible generalization of such criteria to all types of Bafut drama. Only subsequently could attempts be made to further extend the generalization to the entire country, i.e. to Cameroonian drama as a whole drawn from all the other diverse regions and tribes of this country. And pursuing his investigation still further, the researcher could keep broadening the circle, depending on the results obtained, to include the entire African continent and possibly the world. In other words, instead of seeking to determine universals of performability in all drama texts indistinctly, the researcher could attain more pertinent findings whose syntheses and applicability 
could be more readily and fruitfully related to the culture, period and drama type in question. Obviously, such a case by case approach as advocated here seems to confirm and justify the prevailing situation which Bassnett (1991:105) rather highlights with disapproval whereby "most of the existing literature on theatre translation consists of case studies of individual translations and translators, translators' prefaces [...]".

Espasa (2000:49-56) also further opens up perspectives on performability by asserting that performability involves negotiation and by placing theatre ideology and power negotiation at the heart of performability. For her, performability is thus shaped by consideration of status and the 'crucial' question from this perspective then becomes who has power in a theatre company to decide what is performable and what is ruled out as unperformable. However, analyses of the distinct roles of the drama translator and the director as well as the drama communication chain seems to suggest that the above question is not that 'crucial' or does not even arise as it is evident that such power naturally and logically devolves upon the director and the company, and not the translator except the latter, after effecting the translation, were to go on to direct or perform the play himself.

The issue of the performability and speakability of the drama text may not be simply discarded as advocated by Bassnett (1991, 1998). In effect, as prominent Cameroonian playwright and scholar Bole Butake (1988:202) has pointed out, "the ultimate aim of writing a play is usually to see it performed even though it is not always that a play script which is even published finds its way on stage for a number of reasons". In the same vein Makon (1988:262) asserts that:

Un texte théâtral qui n'a pas la possibilité d'être représenté scéniquement est semblable à un monde 
imaginaire, à un projet (aux grandes idées peut-être) dormant dans un tiroir. Il sera lu, relu, mais pas vécu. Il ne sera jamais un 'moment de vie partagé'. Aussi, un créateur théâtral qui se veut constructeur, écrit-il dans la perspective d'une réalisation concrète pour un public. [A play that cannot be staged is like an imaginary world, a scheme (perhaps with lofty ideas) lying in a drawer. It will be read and reread but not lived. It will never be a 'moment of shared life'. Thus, a playwright who wants to be constructive writes with the aim of seeing the play actually performed for a particular audience.]

In this regard, Totzeva (1999:81) has rightly described the play as "a text conceived for possible theatrical performance" and she too has examined the issue of performability or theatrical potential of the dramatic text from a semiotic perspective stating that "in recent semiotic approaches, theoreticians refer to theatricality as a relation between dramatic text and performance". Theatrical potential is understood to mean the semiotic relation between the verbal and nonverbal signs and structures of the performance. She goes on to assert that:

"In a dramatic text this semiotic relation is already to some extent present as a concept through given theatrical codes and norms, although the performance does not need to follow it. [...] Theatrical potential (TP) can be seen as the capacity of a dramatic text to generate and involve different theatrical signs in a meaningful way when it is staged. [...]. The problem for translation as an interlingual transformation of the dramatic text is therefore how to create structures in the target language which can provide and evoke an integration of nonverbal theatrical signs in a performance. (Totzeva1999:81-82).” 
The form of the play itself thus demands dramaturgical capacity to work in several dimensions at once, incorporating visual, gestural, aural and linguistic signifiers into the text. As Brater (1994) points out in his book The Drama in the Text, much of the material in drama often makes more sense when spoken and heard than when simply read and silently digested. It can thus be argued that when a play is written it contains the characteristics/qualities of performability and speakability which the drama translator strives to identify and to preserve in the translation, even when, for reasons deemed justified or not, such characteristics are subsequently subjected to various manipulations by the other persons intervening downstream in the drama communication chain. In effect, it is a well known reality that the original drama text itself as well as its translation are also affected by interpretation on the part of the director, actors and staging devices which influence the mood and atmosphere of the production, such as stage type, pace/movement, light/colour, costume, mask/make-up, music, etc. In this regard, Bassnett (1998:101) has also pointed out that there are a whole range of different ways of reading of the drama text: the director's reading which may involve a process of decision making and the constraints and possibilities offered by the text would be foregrounded in his/her interpretation of it; the actor's reading which would focus on a specific role such that an individual's role is highlighted and other roles perceived as secondary or instrumental; the designer's reading which would involve a visualization of spatial and physical dimensions that the text may open up; the dramaturgical reading and readings by any other individual or group involved in the production process; the rehearsal reading which is subsequent to initial readings and will involve an aural, performance element through the use of paralinguistic signs such as tone, inflexion, pitch, register, etc. It can thus be posited that by paying particular attention to and by examining closely how these different persons of the drama communication chain effect the various readings and by integrating these reading strategies into his own reading and translation 
strategies, the drama translator will offer to the target language director(s) and actors (who in effect constitute the first consumers of his translation before it gets to the audience watching it on stage) a translated version of the play which will, to a large extent, meet their performability expectations.

At yet another level, it can also be asserted that the drama translator's strategies and translational behaviour should equally be informed by the prevailing theatrical practices in the target culture given that these practices often differ from one culture to another. In the Cameroonian context, for instance, directors and actors often introduce or resort to theatrical practices not necessarily built into the play by the playwright. In general, Cameroonian theatrical practices are identified by certain main characteristics. First, there is the introduction by directors of certain characters, who, often feature regularly and prominently in their performances. For instance, there is the narrator/commentator whose role is to render the play in a lively manner and to constantly sustain the attention of the audience. In most plays this character constitutes the heart of the action. He evolves both on the stage and in the hall amongst the audience. He thus serves as a physical bridge between the imaginary world of the actors and the real world of the audience thereby eliminating the barrier that separates the two distinct spaces traditionally reserved for actors and the audience in Western theatres (cf. Doho, 1988:70$1)$.

Another regular and prominent character introduced in Cameroonian theatrical performances is the witchdoctor. René Philombe (in Doho, 1988:76) notes that:

"Qu'il s'agisse de comedies on de tragedies, lesorcierquerisseur et diseur de bonne aventury Est Presque toujours present.Dans 70/100 des pieces de theatre comerounaises on le voit apparaitre et jouer un role important. [Whether in comedies or tragidies, the 
witchdoctor and teller of tales of good fortune is almost always present. He features and plays an important role in $70 \%$ of Cameroonian play.]"

From the textual point of view or from that of staging, the Cameroonian dramatist or director always distinguishes this character from the others by making use of certain signifiers. First, there is the costume, which is usually made of Hessian and old blackened synthetic bags. Then there is the hair-style of long unkempt plaits. Both the costume and hair-style are completed with other apparel such as animal skin and accessories such as cowries, animal horns, snakes, etc. The witchdoctor's appearance is designed to conjure up something strange, unusual and out of the ordinary. Thirdly, there is the speech which comprises two dimensions, depending on whether he is talking to visible or invisible beings, in which case it is either ordinary speech or incantations respectively. If incantations, the language is symbolic and can only be decoded by those who have been initiated into it, since it is such language that he uses to communicate with spirits in the invisible world. The incantations are usually poetic and onomatopoeic and take the form of songs.

Apart from the introduction of the narrator/commentator and the witchdoctor in Cameroonian plays, a third characteristic of this drama and theatrical performances is the introduction of songs and dancing by the dramatists themselves or by the directors. Anyone travelling across the Cameroonian national territory will notice that there is no event in the life of the Cameroonian that is not accompanied by singing and dancing. In the Bafut, Bamileke, Bassa, Bulu, Douala and other tribes the Cameroonian sings and dances in times of joy and in times of sorrow. One can therefore understand how difficult it is for the Cameroonian playwright or the director not to take into account this reality in his/her dramatic composition(s) or performances as the case may be. 
The fourth characteristic of Cameroonian drama and theatrical performances resulting from the introduction of the narrator/commentator and the witchdoctor is the bridging of the gap between actors and spectators. In the Western classical set-up the theatre is composed of two distinct areas: the stage and the hall. The hall is for the audience, for those watching the play, while the stage is the space for the actors where the micro universe of the play is reconstituted. There is usually a barrier that separates the two spaces. In Cameroonian theatrical practices on the contrary, there is no barrier separating the actors from the audience such that the narrator/commentator or the witchdoctor can freely move from the stage to the audience in the hall, or for the audience to freely move to the stage and join in the singing and dancing. Gaining inspiration from the oral tradition, Cameroonian dramatists and directors therefore strive to eliminate the communication gap between actors and the audience such that the latter not only watches and listens but also actively participates in the drama event.

The unity of place of action as it obtains in Western classical drama is also violated in Cameroonian drama and theatrical performances, particularly as in their dramatic compositions or performances most Cameroonian playwrights or directors tend to be fluid in the use of space and time and the plays when performed may sometimes go on for hours on end. In this connection, Mbassi (1988:109) has pointed out that:

"Il y a lieu de retenir que la tendance générale dans le théâtre Camerounais est celle non du lieu unique, mais celle d'une géographie éclatée. L'action, mobile selon les événements se déroule sur une scène multispaciale et renie du coup toute parenté avec la scène classique. [It is worth noting that the general tendency in Cameroonian drama is not that of unity of place but that of several locations of place of action. The action, 
which is mobile and shifting depending on the events, takes place on a scene made up of several locations and has nothing in common with the classical scene]."

It is thus evident from the above characteristics and as asserted by Doho (1988:80) that:

\begin{abstract}
"Le personnage de sorcier est une donnée dramaturgique importante sur le plan de l'écriture et de la représentation. Il entre donc, tout comme le conteur, l'espace scénique éclatée, etc. dans la grammaire dramaturgique que proposent les dramaturges Camerounais. [The character of the witchdoctor is one of the important dramatic elements in dramatical composition and performance. Just like the narrator/commentator, the multiple locations of the action, etc., he is an integral part of the dramatic language that Cameroonian dramatists present to the public.]"
\end{abstract}

At a more practical and pragmatic level, therefore, it may be argued and posited that instead of continuing to spill much ink on the much debated issue of the performability and speakability of translated drama (i.e. whether or not the notions should be discarded, whether or not performability can or does exist, the difficulty and even the impossibility of determining and transferring this dimension to the target text, etc.) drama translators and scholars could achieve more useful and concrete results by examining closely and analyzing (with respect to the various reading strategies and theatrical practices) what directors and performers in each culture/region actually do to the text for it to be performable or speakable and for it to be effectively performed in conformity with the norms and conventions of the given culture/region. From this perspective, they could then be in a better position to determine and describe for a given drama type within a given culture/region the 
criteria that render the drama text performable. Corresponding guiding principles and strategies could then be outlined for the drama translator based on such established criteria. 


\section{REFERENCES}

Aaltonen, S (1993) Rewriting the Exotic: The Manipulation of Otherness in Translated Drama, Proceedings of XIII FIT World Congress. London: Institute of Translation and Interpreting.

_ (1996) Acculturation of the Other: Irish Milieu in Finnish Drama Translation. Target 9 (1).

(2000) Time-Sharing on Stage: Drama Translation in Theatre and Society. Clevedon: Multilingual Matters Ltd.

Bartsch, R (1987) Norms of Language. London: Longman.

Bassnett, S (1998a) Translation Across Culture. Language at Work, British Studies in Applied Linguistics 13.

S. Bassnett \& Lefevere, (eds) (1998b) Still Trapped in the Labyrinth: Further Reflections on Translation and Theatre. Constructing Cultures: Essays in LiteraryTranslation, Clevedon : Multilingual Matters.

(1998c) The Translation Turn in Cultural Studies, S. Bassnett \& A. Lefevere(eds) Constructing Cultures: Essays in Literary Translation,. Clevedon: Multilingual Matters.

(1991) Translating for the Theatre: The Case Against Performability. TTR 4 (1).

(1990) Translating for the Theatre: Textual Complexities. Essays in Poetics. 
(1985) Ways Through the Labyrinth: Strategies and Methods for Translating Theatre Texts. Theo Hermans, (ed), The Manipulation of Literature: Studies in Literary Translation.London: Croom Helm.

(1980) Translation Studies. London: Routledge.

(1978) Translating Spatial Poetry: an Examination of Theatre Texts in Performance. J. Holmes et al (eds),Literature and Translation, Louvain: Acco.

Brater, E (1994) The Drama in the Text. Oxford: Oxford University Press.

Butake, B (1988) The Rise of the Comic Genre in Cameroon Drama: A Case Study of the Dramatic Compositions of Guillaume Oyono Mbia, Cameroonian Theatre. Yaounde: BET \& Co. Ltd.

(1988b) Play Production in Cameroon. Cameroon Theatre. Yaounde: BET \&Co. BET \& Co. Ltd.

Clark, J. P. (1981) Aspects of Nigerian Drama. Drama and Theatre in Nigeria. Nigeria Magazine.

Doho, G (1988) La dette du théâtre camerounais moderne envers l'oralité, Théâtre Camerounais. Yaounde: BET \& Co. Ltd.

Elam, K (1980) The Semiotics of Theatre and Drama. London: Methuen.

Espasa, E (2000) Performability in Translation: Speakability? Playability? Or just Saleability?, C-A Upton (ed) Moving Target: Theatre Translation and Cultural Relocation,. Manchester: St. Jerome Publishing. 
Helbo, A (ed.) (1987) Theory of Performing Arts. Amsterdam: John Benjamins.

(1975) Sémiologie de la représentation: théâtre, télévision, bande dessinée. Bruxelles: Editions Complexes.

Makon, P (1988) Le théâtre camerounais et son public: Quelles relations créatrices. Théâtre Camerounais. Yaounde: BET $\&$ Co. Ltd.

Mbassi, B (1988) L'Ecriture dramatique camerounaise: une écriture à la croisée des chemins. Théâtre Camerounais. Yaounde : BET \& Co. Ltd.

Moravkova, A (1993) Les problèmes spécifiques de la traduction des drames. Proceedings of XIII FIT World Congress. London: Institute of Translation and Interpreting.

Totzeva, S (1999) Realizing Theatrical Potential: The Dramatic Text in Performance Translation. J. Boase-Beier \& M. Holman, (eds), Manchester Practices of Literary Translation: Constraints and Creativity: St. Jerome.

Ubersfeld, A (1996) Lire le théâtre I (Nouvelle édition revue). Paris: Belin.

__ (1978) Lire le théâtre. Paris: Editions Sociales.

Upton, C-A (2000) Moving Target: Theatre Translation and Cultural Relocation. Manchester: St. Jerome.

Wellwarth, G. E (1981) Special Considerations in Drama Translation. Translation Spectrum: Essays in Theory and Practice. Albany: State University of New York Press. 
